\title{
Extracorporeal shock wave therapy (ESWT) versus local corticosteroid injection in treatment of lateral epicondylitis (tennis elbow) in athletes: clinical and ultrasonographic evaluation
}

\author{
Noha Hosni Ibrahim*, Refaat Mostafa El Tanawy, Amal Fathy Soliman Mostafa and Mayada Fawzy Mahmoud
}

\begin{abstract}
Background: Lateral epicondylitis is one of the commonly noticed disorders of the arm described by agony focused over lateral epicondyle which is the site of wrist extensors origin. The purpose of this work was to compare the efficiency of extracorporeal shock wave therapy and local corticoid injection in management of lateral epicondylitis both clinically and ultrasonographically as well as to assess the role of ultrasound in diagnosis and follow-up of lateral epicondylitis. This study was performed on 30 athletes diagnosed as lateral epicondylitis.

Results: Both corticosteroid injection and shock wave treatment showed a highly significant effectiveness on pain by visual analog scale (VAS). A highly significant difference between before treatment and after 2 as well as 4 weeks of treatment regarding the functional disability parameters as patient-rated tennis elbow evaluation (PRTEE) and quick disabilities of the arm, shoulder, and hand (DASH) was found. Likewise, a statistically significant improvement in favor of shock wave therapy group after 2 weeks was found, inversely insignificant difference after 8 and 12 weeks regarding to VAS occurred. Both PRTEE and Quick DASH test showed a statistically significant difference among groups through all follow-up period.

There was a statistically insignificant difference among the studied groups according to ultrasound (US) changes in the form of focal areas of hypo-echogenicity through follow-up periods. A significant improvement in favor of ESWT group is detected among the studied groups regarding tendon thickening in ultrasonography before treatment and after 2 and 4 weeks. However, the difference was insignificant after 8 and 12 weeks.

Conclusions: Both corticosteroid local injection and shock wave therapy are helpful and effective for lateral epicondylitis treatment. However, a shock wave therapy revealed better improvement on long-term clinical and ultrasonogrphic follow-up than corticosteroid injection. Musculoskeletal ultrasound represents a helpful diagnostic and follow-up tool for lateral epicondylitis.
\end{abstract}

Keywords: Lateral epicondylitis, Corticosteroids injection, Shock wave therapy

\footnotetext{
* Correspondence: drnonon@yahoo.com; https://orcid.org/

Department of Rheumatology and Rehabilitation, Benha Faculty of Medicine,

, Al-Qalyubia Governorate, Benha, Egypt
}

\section{Springer Open}

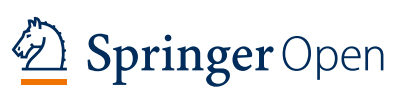

(c) The Author(s). 2021 Open Access This article is licensed under a Creative Commons Attribution 4.0 International License, which permits use, sharing, adaptation, distribution and reproduction in any medium or format, as long as you give appropriate credit to the original author(s) and the source, provide a link to the Creative Commons licence, and indicate if changes were made. The images or other third party material in this article are included in the article's Creative Commons licence, unless indicated otherwise in a credit line to the material. If material is not included in the article's Creative Commons licence and your intended use is not permitted by statutory regulation or exceeds the permitted use, you will need to obtain permission directly from the copyright holder. To view a copy of this licence, visit http://creativecommons.org/licenses/by/4.0/. 


\section{Background}

Lateral epicondylitis (LE), also known as tennis elbow, is a familiar musculoskeletal disorder that affects $1-3 \%$ of the adult populace and 2 and $23 \%$ of the operating populace [1]. It is presented by tenderness over the lateral epicondyle of the humerus, associated with pain on resisted wrist dorsiflexion [2]. It grows because of tedious motions of the prime and elbow, such as the working, forehand, and backhand changes in tennis and other noise sports. It is a normal sports damage, happening in up to $50 \%$ of athletes whose sports include regular overarm actions [3]. LE is typically diagnosed using clinical criteria as well as imaging techniques, including musculoskeletal ultrasonography [4]. Tendon alterations noted with gray-scale MSUS of the common extensor tendon of people with LE involve tendon thickening, changes in fibrillar pattern, focal parts of tendon hypo echogenicity, and/or bone spurs and anomalies [5]. The decision of therapy for each case stays contentious and is built on the personal understanding of the curing physician. Many conservative therapies have been recommended, involving non-steroidal anti-inflammatory drugs, physical modalities, i.e., as ultrasound, low-dose laser treatment, corticosteroids insertion, efficient brace, and manipulative therapy but none has exhibited reliable outcomes [6]. Extracorporeal shock wave therapy (ESWT) or else denoted to as shockwave therapy is a commonly utilized form of therapy. Several studies stated that ESWT has been administered in refractory LE treatment when conservative measures fail [7-10]. It includes focused single-pressure pulses of microsecond length and was initially utilized for medicinal targets in renal calculi treatment. In the 1990s, ESWT developed a prevalent in Germany for soft-tissue ailments, involving petrifying rotator cuff tendonitis, humeral epicondylitis, and plantar fasciitis. It is now utilized worldwide for musculoskeletal complaints treatment [11]. Local corticosteroid (CS) injection signifies a general tactic for treating numerous musculoskeletal syndromes. It is an easy, economical procedure, designed at lessening pain, and other signs related to inflammatory processes. Corticosteroid suppresses the immune system by controlling the proinflammatory proteins [12].

\section{Methods}

\section{Target population}

\section{Inclusion criteria}

This study was carried out on thirty athletes (tennis and squash players) suffering from lateral epicondylitis, recalibrated to conservative treatment including NSAIDs and physiotherapy for 3 months with failure of the conservative treatment. They were recruited from the outpatients' clinic of Rheumatology, Rehabilitation, and Physical Medicine department, Benha university hospitals.
Lateral epicondylitis was diagnosed when pain is elicited by two or more of these diagnostic exams [13]:

1. Palpation of the lateral epicondyle

2. Resisted wrist extension (Thompson test)

3. Chair test. With the shoulder flexed to $60^{\circ}$ and the elbow extended, the patient attempts to lift a chair weighing $3.5 \mathrm{~kg}$

\section{Exclusion criteria}

Patients with the subsequent circumstances were omitted from this study:

- Age less than 18 years

- Presence of cervical or upper extremity pathology

- History of elbow joint operation

- Elbow joint arthritis

- Limited ROM of the joint

- Pregnancy

- Tumor or local infection of the upper extremity

- Implanted pacemaker

- Patients who had obtained a corticosteroid insertion for lateral epicondylitis within the prior 6 months

The study population was randomly assigned to receive either corticosteroid injection or ESWT sessions (Fig. 1).

Group 1 included 15 patients who received local corticosteroid injection for treatment of lateral epicondylitis in the form of $40 \mathrm{mg}$ methyl prednisolone with $1 \mathrm{ml}$ mepacaine at the point with utmost tenderness in the lateral epicondyle area.

Group 2 included 15 patients who received shock wave therapy using radial ESWT for 1 session per week 3 successive sessions.

The ESWT apparatus was set on these parameters.

Time: 02:05 min:s

Pressure: 1.2 Bar

Frequency: $4.0 \mathrm{~Hz}$

Shock number: $500 \mathrm{~N}$

Energy density: $0.144 \mathrm{mj} / \mathrm{mm}^{2}$

\section{Clinical assessment}

1- Assessment of pain severity by visual analog scale (VAS): The patient rates pain he experienced from 1 to10 and then recorded. VAS-zero score is the least pain, while the VAS 10.0 points to the worst pain [14].

2- Assessment of forearm pain and functional disability by patient-rated tennis elbow evaluation (PRTEE). PRTEE involves assessment of difficulty amount for the patient had with the arm in the 
preceding week by describing the regular arm signs over the past week on a level of 0-10 [15].

3- Patient capability to operate daily activities was evaluated using Quick DASH (Disabilities of the Arm, Shoulder and Hand) questionnaire. The Quick DASH is a shortened edition of the original DASH result amount. In similarity to the initial 30item DASH ending amount, the Quick DASH only includes 11 elements. It is a survey that evaluates an entity's capacity to fulfill duties, attract forces, and simplicity of signs. The Quick DASH tool utilizes a 5 -step Likert scale from which the patient can choose a suitable number relating to his/her severity/function level [16].

\section{Ultrasonic evaluation}

Ultrasonography was performed using Logiq P9 US machine with a high frequency and linear array transducer (12-15 MHz), both gray and power Doppler scale according to the EULAR guidelines. Focus, depth, and gain are adjusted for better image quality for detection of one or more signs of these ultrasonographic features:

Common extensor tendon thickening compared with the other side. The focal areas of tendon hypo echogenicity, disturbed fibrillar pattern, intra-tendon calcification, and bone spurs [5].

All patients were evaluated clinically and ultrasonographically at baseline, at 2-, 4-, 8-, and 12-week posttreatment.

\section{Outcome measures}

Our primary outcome measures included alteration of elbow pain by VAS and PRTEE and changes of patient performance of daily activities by Quick DASH test. The secondary outcome measures were ultrasonographic common extensor origin tendon (CEO) changes.

\section{Ethical consideration}

Written approvals permitting to the Helsinki Declaration were taken from all patients before membership in the study that was authorized by the ethical board of our institute.

\section{Data management}

The clinical data was verified on a narrative form. These data were arranged and analyzed using SPSS version 26 to acquire:

\section{Descriptive data}

Factual statistics were estimated for the data in the form of the following:

1. Mean and standard deviation $( \pm S D)$ for quantifiable data

\section{Frequency and distribution for qualitative data Analytical statistics}

In the statistical assessment among the diverse groups, the consequence of disparity was examined using one of the subsequent tests:

1- Student's $t$ test: Used to assess the mean of two parties of quantifiable data

2- Paired $t$ test: Used to assess the mean of variables in various time phases of quantifiable data.

3- Inter-group evaluation of categorical data was executed using chi-square test $\left(X^{2}\right.$ value) and Fisher exact test (FET).

A $p$ value $\leq 0.05$ was considered statistically significant $(*)$ while $>0.05$ statistically insignificant $p$ value $\leq 0.01$ was considered highly significant $(* *)$ in all analysis.

\section{Results}

Thirty patients were enrolled in this prospective randomized controlled clinical study. The mean age of the studied cases was $31.7 \pm 6.74$ years ranged from 19 to 44 years. There was male predominance about $73.3 \%$. The mean weight was $82.87 \mathrm{~kg}$, while the mean height was $1.69 \mathrm{~m}$. Most of the studied cases (90\%) had right dominant hand and laterality of painful hand. The mean duration of the disease was $4.13 \pm 2.22$ months. There was a statistically insignificant variation between CS injection and ESWT groups concerning to age, gender, weight, height, BMI, dominant hand, laterality of painful hand, and duration of disease (Table 1).

Chair test was negative in $73.3 \%$ of the cases after 2 weeks, and in $83.3 \%$ of the cases after 4 weeks, following by $96.7 \%$ of the cases after 8 weeks and 12 weeks simultaneously. Thompson test was negative in $70 \%$ of the cases after 2 weeks, $83.3 \%$ of the cases after 4 weeks, while $96.7 \%$ of the cases after 8 weeks and 12 weeks were found as plotted in Fig. 2.

There was a statistically insignificant difference among the studied groups regarding the results of chair and Thompson tests through follow-up periods $(2,4,8$, and 12 weeks) with $p=0.22,0.33,1.0$, and 1.0 , respectively for chair test. And it was reached $p$ $=0.11,0.33,1.0$, and 1.0 respectively for Thompson test as displayed in Table 2.

There was a high statistically significant variation among the studied groups according to VAS, PRTEE, and Quick DASH test after 2, 4, 8, and 12 weeks with $p 1$ $<0.001$. Likewise, there was a high statistically significant difference among the studied groups according to VAS, PRTEE, and Quick DASH test after 2 weeks, as well as after 4,8 , and 12 weeks with $p 2<0.001$ (Fig. 3).

There was a statistically meaningful variation between groups 1 and 2 in favor of group 1 after 2 weeks, but 
Table 1 Comparison between the studied groups according to personal data

\begin{tabular}{|c|c|c|c|c|c|c|}
\hline & \multicolumn{2}{|c|}{ CS injection (15) (group 1) } & \multicolumn{2}{|c|}{ ESWT (15) (group 2) } & \multirow{2}{*}{$\begin{array}{l}\text { Statistical } \\
\text { test }\end{array}$} & \multirow{2}{*}{$\begin{array}{l}p \\
\text { value }\end{array}$} \\
\hline & Mean & $\pm \mathrm{SD}$ & Mean & $\pm \mathrm{SD}$ & & \\
\hline Age & 31.0 & 7.32 & 32.4 & 6.29 & St $t=0.56$ & 0.58 \\
\hline \multicolumn{7}{|l|}{ Gender, $n$ (\%) } \\
\hline Male & $10(66.7)$ & & $12(80.0)$ & & $\mathrm{FET}=0.17$ & 0.68 \\
\hline Female & $5(33.3)$ & & $3(20.0)$ & & & \\
\hline Weight (kg) & 81.27 & 8.65 & 84.47 & 6.39 & St $t=1.15$ & 0.26 \\
\hline Height (m) & 1.69 & 0.082 & 1.68 & 0.075 & St $t=0.39$ & 0.70 \\
\hline BMI (kg/m) & 28.48 & 3.3 & 30.02 & 2.76 & St $t=1.39$ & 0.18 \\
\hline \multicolumn{7}{|l|}{ Dominant hand, $n(\%)$} \\
\hline Rt & $14(93.3)$ & & $13(86.7)$ & & $\mathrm{FET}=0.0$ & 1.0 \\
\hline $\mathrm{Lt}$ & $1(6.7)$ & & $2(13.3)$ & & & \\
\hline \multicolumn{7}{|l|}{ Laterality of painful hand, $n(\%)$} \\
\hline Rt & $13(86.7)$ & & $13(86.7)$ & & $\mathrm{FET}=0.0$ & 1.0 \\
\hline$L t$ & $2(13.3)$ & & $2(13.3)$ & & & \\
\hline Duration of disease (month) & 3.93 & 2.19 & 4.33 & 2.32 & St $t=0.49$ & 0.63 \\
\hline
\end{tabular}

$C S$, corticosteroid; $E S W T$, extracorporeal shock wave therapy; $B M I$, body mass index; $R t$, right; $L t$, left; $n$, number

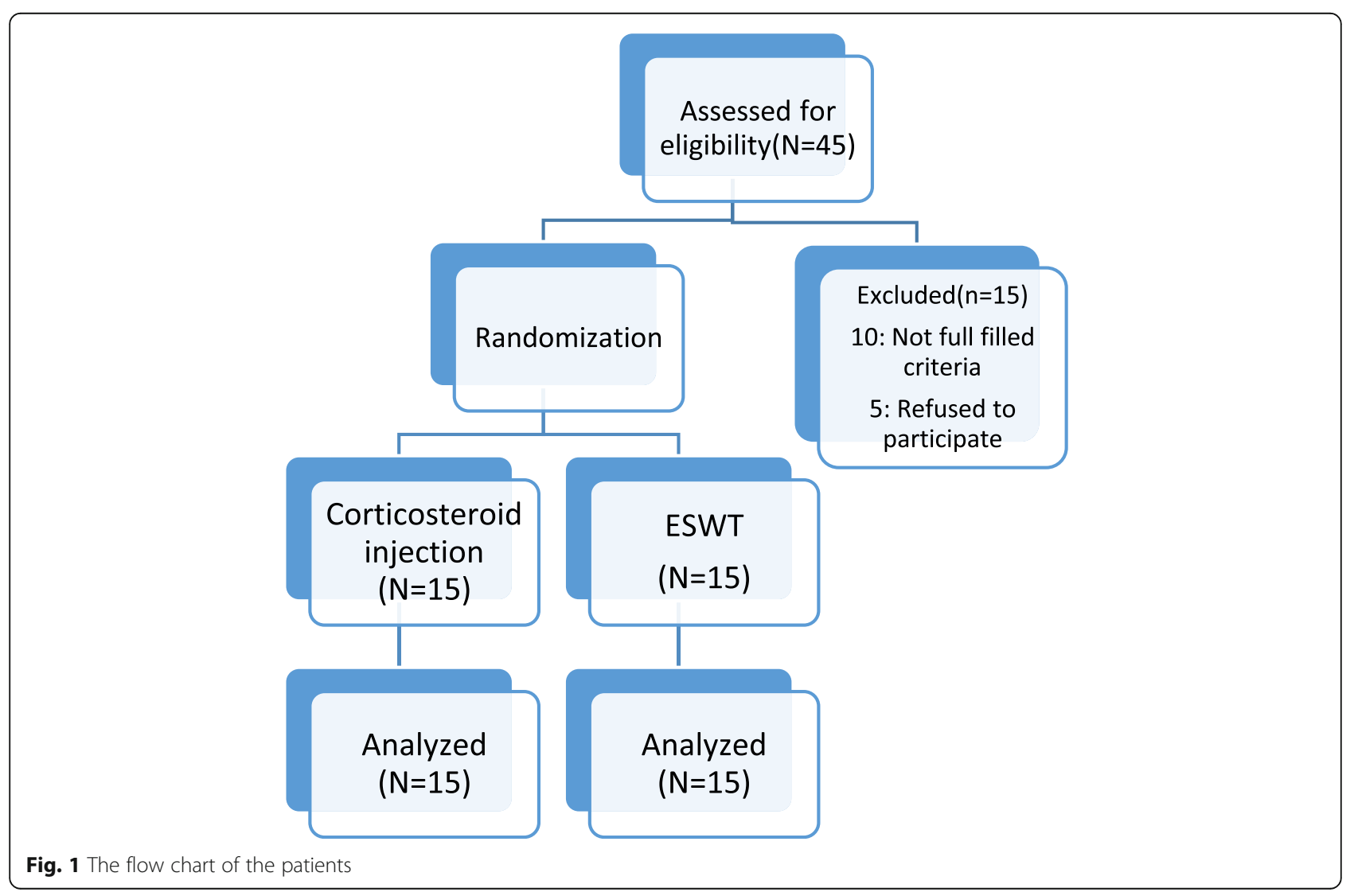




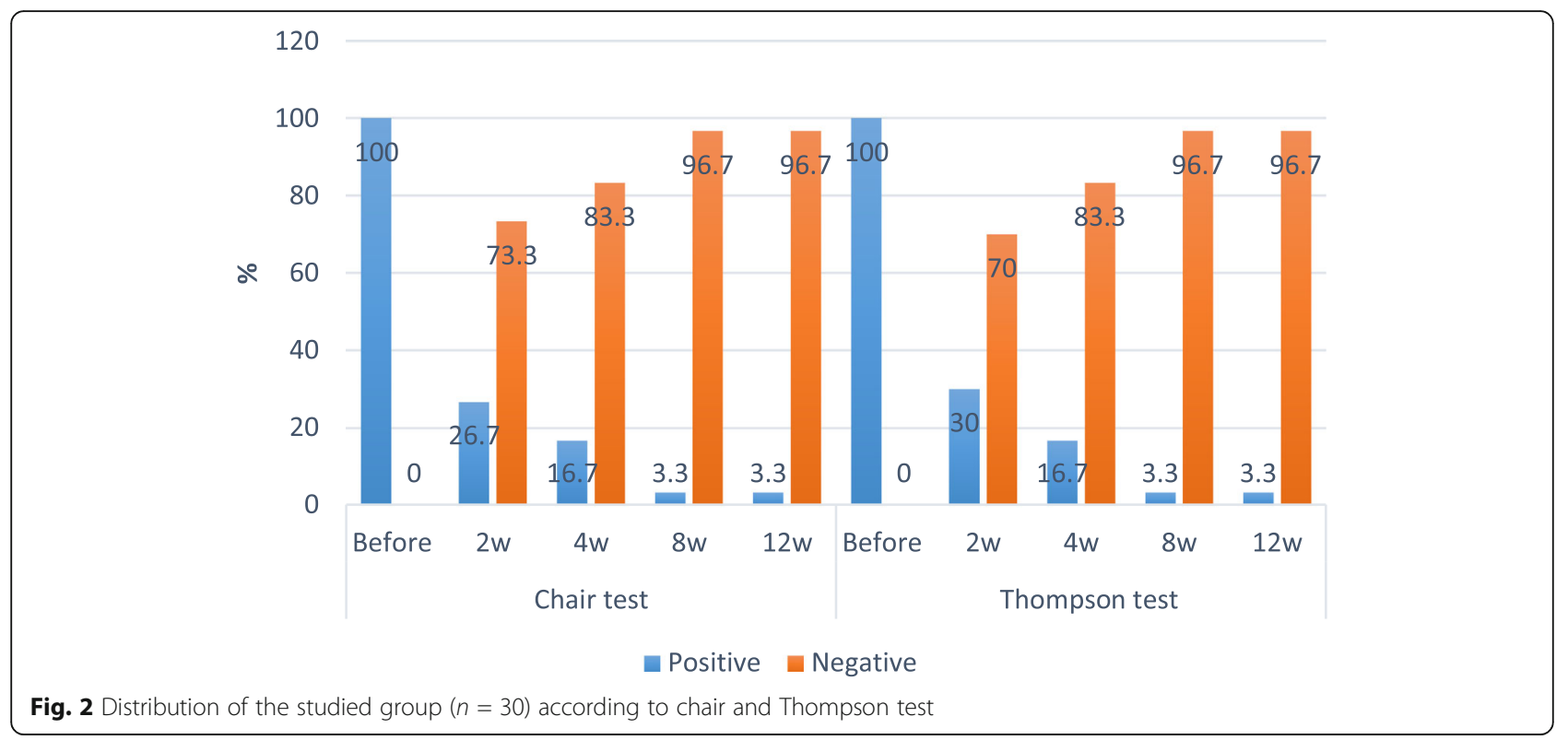

insignificant difference after 8 and 12 weeks regarding the VAS test was noted. As regard to PRTEE, there was a statistically significant difference among all groups after 2, 4, and 12 weeks of treating. There was a statistically considerable improvement among groups regarding the Quick DASH test after 2, 4, and 12 weeks of treatment (Table 3).

VAS, PRTEE, and Quick DASH test show a highly statistically significant difference among corticosteroid injection groups before and after 2, 4, 8, and 12 weeks of treatment with $p 1<0.001$.

VAS, PRTEE, and Quick DASH test show a highly statistically significant difference among corticosteroid injection groups after $2,4,8$, and 12 weeks with $p 2<$ 0.001 , while the difference was insignificant after 12 weeks for VAS (Table 4).

VAS, PRTEE, and Quick DASH test show a high significant difference among ESWT group before and after $2,4,8$, and 12 weeks of treatment with $p 1$ and $p 2<$ 0.001 (Table 5).

An $86.7 \%$ of the studied cases had positive US changes in the form of focal areas of hypo-echogenicity after 2 weeks, meanwhile only $30 \%$ had positive US changes after 4 weeks. Furthermore, only $13.3 \%$ had positive US changes after 8 weeks and $10 \%$ had positive US changes after 12 weeks of treatment (Table 6).

There was a statistically insignificant improvement in favor of ESWT group among the studied groups according to US changes in the form of focal areas of hypoechogenicity through follow-up periods $(2,4,8$, and 12 weeks), with $p=0.10,0.11,1.0$, and 1.0 , respectively.

As regards to tendon thickening, it was positive in $76.7 \%$ of the cases before, while after 2 weeks it was positive in $63.3 \%$ of the studied cases and it was positive in only $33.3 \%$ of the studied cases after 4 weeks. After 8 weeks of treating, it was positive in $13.3 \%$, and after 12 weeks it was positive in $3.3 \%$ from all the studied cases (Table 6).

There was a statistically significant improvement in favor of ESWT group among the studied groups regarding tendon thickening after 2 and 4 weeks with $p=$ 0.021 and 0.002 , respectively. After 8 and 12 weeks, there was a statistically insignificant difference in favor of ESWT group. Regarding other US changes including disturbed fibrillar pattern, power Doppler signals, intratendon calcifications, and bone spurs the differences between both groups through follow-up periods were nonsignificant (Table 6, Figs. 4a, b and 5a, b).

\section{Discussion}

The aim of the current research was to evaluate the effectiveness of extracorporeal shock wave treatment and local corticosteroid injection in management of tennis elbow in athletes both clinically and ultrasonographically. In our study, the highly significant productivity of ESWT on pain and operational incapacity parameters symbolized in VAS, PRTEE, and Quick DASH test showed a high significant improvement among ESWT group before and after 2, 4, 8, and 12 week. This is concurred with Maffulli et al. [17], who performed a research on 59 patients with LE obtaining 3 sessions of ESWT. He stated a significant progress concerning the VAS score and PRTEE score after 3, 6, 12, and 24 months of follow-up. Similarly, Ismael et al. [18] and Aydin and Atic [19] stated that there were a statistically considerable reduction of VAS and PRTEE scores and a 
Table 2 Comparison between the studied groups according to results of chair and Thompson tests through follow-up periods

\begin{tabular}{|c|c|c|c|c|c|c|c|}
\hline & & \multicolumn{2}{|c|}{ CS injection (15) (group 1) } & \multicolumn{2}{|c|}{ ESWT (15) (group 2) } & \multirow{2}{*}{$\begin{array}{l}\text { Statistical } \\
\text { test (FET) }\end{array}$} & \multirow{2}{*}{$\begin{array}{l}p \\
\text { value }\end{array}$} \\
\hline & & No. & $\%$ & No. & $\%$ & & \\
\hline \multirow[t]{15}{*}{ Chair test } & Before & & & & & & \\
\hline & Positive & 15 & 100 & 15 & 100 & - & - \\
\hline & Negative & 0 & 0.0 & 0 & 0.0 & & \\
\hline & $2 w$ & & & & & & \\
\hline & Positive & 2 & 13.3 & 6 & 40.0 & 1.53 & 0.22 \\
\hline & Negative & 13 & 86.7 & 9 & 60.0 & & \\
\hline & $4 w$ & & & & & & \\
\hline & Positive & 1 & 6.7 & 4 & 26.7 & 0.96 & 0.33 \\
\hline & Negative & 14 & 93.3 & 11 & 73.3 & & \\
\hline & $8 w$ & & & & & & \\
\hline & Positive & 1 & 6.7 & 0 & 0.0 & 0.0 & 1.0 \\
\hline & Negative & 14 & 93.3 & 15 & 100 & & \\
\hline & $12 \mathrm{w}$ & & & & & & \\
\hline & Positive & 1 & 6.7 & 0 & 0.0 & 0.0 & 1.0 \\
\hline & Negative & 14 & 93.3 & 15 & 100 & & \\
\hline \multirow[t]{15}{*}{ Thompson test } & Before & & & & & & \\
\hline & Positive & 15 & 100 & 15 & 100 & - & - \\
\hline & Negative & 0 & 0.0 & 0 & 0.0 & & \\
\hline & $2 w$ & & & & & & \\
\hline & Positive & 2 & 13.3 & 7 & 46.7 & 2.54 & 0.11 \\
\hline & Negative & 13 & 86.7 & 8 & 53.3 & & \\
\hline & $4 w$ & & & & & & \\
\hline & Positive & 1 & 6.7 & 4 & 26.7 & 0.96 & 0.33 \\
\hline & Negative & 14 & 93.3 & 11 & 73.3 & & \\
\hline & $8 w$ & & & & & & \\
\hline & Positive & 1 & 6.7 & 0 & 0.0 & 0.0 & 1.0 \\
\hline & Negative & 14 & 93.3 & 15 & 100 & & \\
\hline & $12 w$ & & & & & & \\
\hline & Positive & 1 & 6.7 & 0 & 0.0 & 0.0 & 1.0 \\
\hline & Negative & 14 & 93.3 & 15 & 100 & & \\
\hline
\end{tabular}

CS, corticosteroid; ESWT, extracorporeal shock wave therapy; w, week

substantial expansion of functional measure represented in hand grip intensity at 4 weeks of follow-up and 12 weeks of follow-up in the ESWT group.

In contrast, Buchbinder et al. [20] performed a systematic review and described that there was an evidence that extracorporeal shock wave therapy offered no or little impact in pain and purpose in LE patients.

In some studies, the efficacy of shock wave therapy in the treatment of lateral epicondylitis has been investigated, and success rates ranging between 68 and 91\% have been reported [21]. However, some studies have showed that shock wave therapy has either no therapeutic effect or been less effective than the placebo $[20,21]$.
In a pool study achieved by Reza Nourbakhsh et al. [22] and Mehra et al. [23] regarding ESWT, the authors stated $50 \%$ pain relief within 12 weeks of follow-up period with ESWT. Spacca et al. [24] reported a significant pain relief with shock wave therapy within 12 weeks of the follow-up period when compared with the placebo.

Collins and Jafarnia [25] also found a significant decrease in pain aggravation with activity using ESWT during 8 weeks of the follow-up period.

The cause for the contradictory findings of ESWT on LE might be the variations in the pulses number, duration, frequency, treatment interval, and diverse devices applied, relying on the variable protocols applied in 


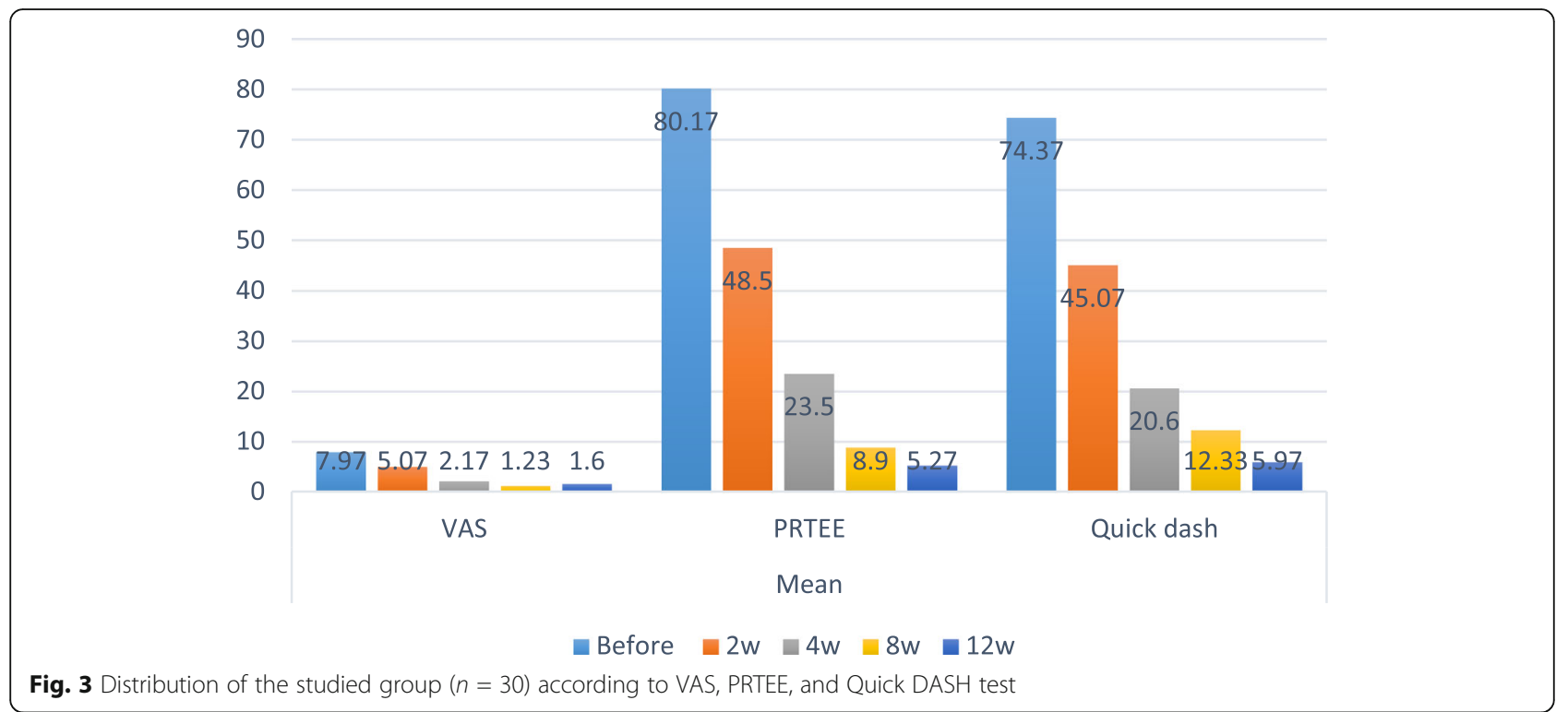

treatment. This may be when the literature is amended, it is seen that ESWT does not have a standard protocol used for medication of LE.

When a shock wave targets a tissue, it produces two physical effects: The stress-associated phenomenon persuaded by the ultra-short upsurge time about $5 \mathrm{~ns}$ and the cavitation bubbles formed at the edge between the solid and the neighboring liquid. These two actions work synergically to produce the short-wave effect. ESWT promotes soft tissue healing mainly by suppressing afferent pain-receptor function in the first hours After that, in the next few days, by downregulating the production of inflammatory cytokines [26], and by increasing the angiogenesis and, at about the 28-30th day, by refining cellular proliferation and the creation of the extra-cellular matrix [27].

In our study, the highly significant efficacy of CS injection on pain and functional incapacity parameters such as VAS, PRTEE, and Quick DASH test showed a high significant improvement among CS injection group after

Table 3 Comparison between the studied groups according to VAS, PRTEE, and Quick DASH test through follow-up periods

\begin{tabular}{|c|c|c|c|c|c|c|c|}
\hline & & \multicolumn{2}{|c|}{$\begin{array}{l}\text { CS injection (15) } \\
\text { Group } 1\end{array}$} & \multicolumn{2}{|c|}{$\begin{array}{l}\text { ESWT (15) } \\
\text { Group } 2\end{array}$} & \multirow[t]{2}{*}{$\begin{array}{l}\text { Statistical } \\
\text { test (st t) }\end{array}$} & \multirow[t]{2}{*}{$p$ value } \\
\hline & & Mean & $\pm \mathrm{SD}$ & Mean & $\pm \mathrm{SD}$ & & \\
\hline \multirow[t]{5}{*}{ VAS } & Before & 7.33 & 1.76 & 8.6 & 0.83 & 2.52 & $0.018^{*}$ \\
\hline & $2 w$ & 4.33 & 1.76 & 5.8 & 1.7 & 2.32 & $0.028^{*}$ \\
\hline & $4 w$ & 1.6 & 1.6 & 2.73 & 2.25 & 1.59 & 0.12 \\
\hline & $8 w$ & 1.6 & 1.6 & 0.87 & 0.92 & 1.55 & 0.134 \\
\hline & $12 w$ & 3.07 & 7.05 & 0.13 & 0.35 & 1.61 & 0.119 \\
\hline \multirow[t]{5}{*}{ PRTEE } & Before & 78.2 & 11.79 & 82.13 & 8.08 & 1.07 & 0.30 \\
\hline & $2 w$ & 35.67 & 16.92 & 61.33 & 11.21 & 4.9 & $<0.001^{* *}$ \\
\hline & $4 w$ & 14.93 & 18.65 & 32.07 & 20.17 & 2.42 & $0.022^{*}$ \\
\hline & $8 w$ & 11.73 & 12.7 & 6.07 & 3.1 & 1.68 & 0.104 \\
\hline & $12 w$ & 9.07 & 8.74 & 1.47 & 1.3 & 3.33 & $0.002^{* *}$ \\
\hline \multirow[t]{5}{*}{ Quick DASH } & Before & 73.33 & 14.16 & 75.4 & 11.14 & 0.44 & 0.66 \\
\hline & $2 w$ & 35.6 & 16.96 & 54.53 & 12.55 & 3.48 & $0.002^{* *}$ \\
\hline & $4 w$ & 13.33 & 16.83 & 27.87 & 17.46 & 2.32 & $0.028^{*}$ \\
\hline & $8 w$ & 12.47 & 15.1 & 12.2 & 9.69 & 0.06 & 0.96 \\
\hline & $12 w$ & 9.73 & 9.21 & 2.2 & 2.24 & 3.08 & $0.005^{* *}$ \\
\hline
\end{tabular}

VAS, visual analog scale; PRTEE, patient-rated tennis elbow evaluation; DASH, disabilities of the arm, shoulder, and hand; $w$, week; CS, corticosteroid; ESWT, extracorporeal shock wave therapy 
Table 4 Comparison of VAS, PRTEE, and Quick DASH test through follow-up periods among CS injection group $1(n=15)$

\begin{tabular}{|c|c|c|c|c|c|c|c|}
\hline \multirow{2}{*}{\multicolumn{2}{|c|}{$\begin{array}{l}\text { CS injection (15) } \\
\text { Group } 1\end{array}$}} & \multirow[t]{2}{*}{ Mean } & \multirow[t]{2}{*}{$\pm \mathrm{SD}$} & \multicolumn{2}{|l|}{ Before } & \multicolumn{2}{|l|}{$2 w$} \\
\hline & & & & Paired $t 1$ & $p 1$ & Paired $t 2$ & $p 2$ \\
\hline \multirow[t]{5}{*}{ VAS } & Before & 7.33 & 1.76 & & & & \\
\hline & $2 w$ & 4.33 & 1.76 & 9.27 & $<0.001^{* *}$ & & \\
\hline & $4 w$ & 1.6 & 1.6 & 12.68 & $<0.001^{* *}$ & 8.66 & $<0.001^{* *}$ \\
\hline & $8 w$ & 1.6 & 1.6 & 12.68 & $<0.001^{* *}$ & 8.66 & $<0.001^{* *}$ \\
\hline & $12 \mathrm{w}$ & 3.07 & 7.05 & 2.38 & $0.032^{*}$ & 0.78 & 0.446 \\
\hline \multirow[t]{5}{*}{ PRTEE } & Before & 78.2 & 11.79 & & & & \\
\hline & $2 w$ & 35.67 & 16.92 & 9.82 & $<0.001^{* *}$ & & \\
\hline & $4 w$ & 14.93 & 18.65 & 13.44 & $<0.001^{* *}$ & 8.18 & $<0.001^{* *}$ \\
\hline & $8 w$ & 11.73 & 12.7 & 19.07 & $<0.001^{* *}$ & 10.8 & $<0.001^{* *}$ \\
\hline & $12 w$ & 9.07 & 8.74 & 22.88 & $<0.001^{* *}$ & 10.06 & $<0.001^{* *}$ \\
\hline \multirow[t]{5}{*}{ Quick DASH } & Before & 73.33 & 14.16 & & & & \\
\hline & $2 w$ & 35.6 & 16.96 & 8.46 & $<0.001^{* *}$ & & \\
\hline & $4 w$ & 13.33 & 16.83 & 12.68 & $<0.001^{* *}$ & 7.32 & $<0.001^{* *}$ \\
\hline & $8 w$ & 12.47 & 15.1 & 13.83 & $<0.001^{* *}$ & 7.98 & $<0.001^{* *}$ \\
\hline & $12 w$ & 9.73 & 9.21 & 17.76 & $<0.001^{* *}$ & 9.07 & $<0.001^{* *}$ \\
\hline
\end{tabular}

Paired $t$ test. VAS, visual analog scale; PRTEE, patient-rated tennis elbow evaluation; DASH, disabilities of the arm, shoulder, and hand; $w$, week; CS,

corticosteroid injection

$2,4,8$, and 12 weeks of treatment. This is in parallel to the study of Smidt et al. [28] that contained thirteen studies, to assess the efficiency of CS injection compared to placebo administration, local anesthetic insertion, or another traditional therapy in LE. For short-term effects ( $\leq 6$ weeks), there were significant differences that were observed on pain relief, global improvement, and hand grip intensity for CS insertion equated to other therapy alternatives. Similar outcomes also have been informed by others in the literature $[29,30]$.

Ismael et al. [18] also reported a significant reduction of VAS and PRTEE totals at 4 and 12 weeks of follow-up.

Conversely, Lindenhovius et al. [31] compared CS injection to placebo insertion and found no meaningful variations in the pain and functional incapacity scores, in both short-term and long-term follow-up.

Table 5 Comparison of VAS, PRTEE, and Quick DASH test through follow-up periods among ESWT group $(n=15)$

\begin{tabular}{|c|c|c|c|c|c|c|c|}
\hline \multirow{2}{*}{$\begin{array}{l}\text { ESWT (15) } \\
\text { Group } 2\end{array}$} & & \multirow[t]{2}{*}{ Mean } & \multirow[t]{2}{*}{$\pm \mathrm{SD}$} & \multicolumn{2}{|l|}{ Before } & \multicolumn{2}{|l|}{$2 w$} \\
\hline & & & & Paired $t 1$ & $p 1$ & Paired $t 2$ & $p 2$ \\
\hline \multirow[t]{5}{*}{ VAS } & Before & 8.6 & 0.83 & & & & \\
\hline & $2 w$ & 5.8 & 1.7 & 7.61 & $<0.001^{* *}$ & & \\
\hline & $4 w$ & 2.73 & 2.25 & 11.6 & $<0.001^{* *}$ & 8.56 & $<0.001^{* *}$ \\
\hline & $8 w$ & 0.87 & 0.92 & 37.5 & $<0.001^{* *}$ & 16.43 & $<0.001^{* *}$ \\
\hline & $12 \mathrm{w}$ & 0.13 & 0.35 & 44.12 & $<0.001^{* *}$ & 15.16 & $<0.001^{* *}$ \\
\hline \multirow[t]{5}{*}{ PRTEE } & Before & 82.13 & 8.08 & & & & \\
\hline & $2 w$ & 61.33 & 11.21 & 8.97 & $<0.001^{* *}$ & & \\
\hline & $4 w$ & 32.07 & 20.17 & 11.19 & $<0.001^{* *}$ & 8.47 & $<0.001^{* *}$ \\
\hline & $8 w$ & 6.07 & 3.10 & 42.18 & $<0.001^{* *}$ & 23.15 & $<0.001^{* *}$ \\
\hline & $12 \mathrm{w}$ & 1.47 & 1.3 & 42.15 & $<0.001^{* *}$ & 22.42 & $<0.001^{* *}$ \\
\hline \multirow[t]{5}{*}{ Quick DASH } & Before & 75.4 & 11.14 & & & & \\
\hline & $2 w$ & 54.53 & 12.55 & 9.23 & $<0.001^{* *}$ & & \\
\hline & $4 w$ & 27.87 & 17.46 & 12.89 & $<0.001^{* *}$ & 8.74 & $<0.001^{* *}$ \\
\hline & $8 w$ & 12.2 & 9.69 & 25.94 & $<0.001^{* *}$ & 19.81 & $<0.001^{* *}$ \\
\hline & $12 w$ & 2.2 & 2.24 & 28.05 & $<0.001^{* *}$ & 17.86 & $<0.001^{* *}$ \\
\hline
\end{tabular}

Paired $t$ test. VAS, visual analog scale; PRTEE, patient-rated tennis elbow evaluation; DASH, disabilities of the arm, shoulder, and hand; $w$, week; ESWT, extracorporeal shock wave therapy 
Table 6 Comparison between the studied groups according to US changes through follow-up periods

\begin{tabular}{|c|c|c|c|c|c|c|c|}
\hline \multirow{2}{*}{$\begin{array}{l}\text { US changes } \\
\text { Focal areas of hypoechogenicity }\end{array}$} & \multirow[b]{2}{*}{ Before } & \multicolumn{2}{|c|}{$\begin{array}{l}\text { CS injection group (15) } \\
\text { No. } \%\end{array}$} & \multicolumn{2}{|c|}{$\begin{array}{l}\text { ESWT group (15) } \\
\text { No. } \%\end{array}$} & \multirow[t]{2}{*}{ Statistical test (FET) } & \multirow[t]{2}{*}{$p$ value } \\
\hline & & & & & & & \\
\hline & Positive & 15 & 100 & 15 & 100 & - & - \\
\hline & Negative & 0 & 0.0 & 0 & 0.0 & & \\
\hline & $2 w$ & & & & & & \\
\hline & Positive & 11 & 73.3 & 15 & 100 & 2.60 & 0.10 \\
\hline & Negative & 4 & 26.7 & 0 & 0.0 & & \\
\hline & $4 w$ & & & & & & \\
\hline & Positive & 2 & 13.3 & 7 & 46.7 & 2.54 & 0.11 \\
\hline & Negative & 13 & 86.7 & 8 & 53.3 & & \\
\hline & $8 w$ & & & & & & \\
\hline & Positive & 2 & 13.3 & 2 & 13.3 & 0.0 & 1.0 \\
\hline & Negative & 13 & 86.7 & 13 & 86.7 & & \\
\hline & $12 w$ & & & & & & \\
\hline & Positive & 2 & 13.3 & 1 & 6.7 & 0.0 & 1.0 \\
\hline & Negative & 13 & 86.7 & 14 & 93.3 & & \\
\hline \multirow[t]{15}{*}{ Tendon thickening } & Before & & & & & & \\
\hline & Positive & 10 & 66.7 & 13 & 86.7 & 0.75 & 0.39 \\
\hline & Negative & 5 & 33.3 & 2 & 13.3 & & \\
\hline & $2 w$ & & & & & & \\
\hline & Positive & 6 & 40.0 & 13 & 86.7 & 5.17 & $0.021^{*}$ \\
\hline & Negative & 9 & 60.0 & 2 & 13.3 & & \\
\hline & $4 w$ & & & & & & \\
\hline & Positive & 1 & 6.7 & 9 & 60.0 & $x^{2}=9.6$ & $0.002^{* *}$ \\
\hline & Negative & 14 & 93.3 & 6 & 40.0 & & \\
\hline & $8 w$ & & & & & & \\
\hline & Positive & 1 & 6.7 & 3 & 20.0 & 0.29 & 0.60 \\
\hline & Negative & 14 & 93.3 & 12 & 80.0 & & \\
\hline & $12 w$ & & & & & & \\
\hline & Positive & 1 & 6.7 & 0 & 0.0 & 0.0 & 1.0 \\
\hline & Negative & 14 & 93.3 & 15 & 100 & & \\
\hline \multirow[t]{13}{*}{ Disturbed fibrillar pattern } & Before & & & & & & \\
\hline & Positive & 15 & 100 & 15 & 100 & - & - \\
\hline & Negative & 0 & 0.0 & 0 & 0.0 & & \\
\hline & $2 w$ & & & & & & \\
\hline & Positive & 13 & 86.7 & 14 & 93.3 & $\mathrm{FET}=0.0$ & 1.0 \\
\hline & Negative & 2 & 13.3 & 1 & 6.7 & & \\
\hline & $4 w$ & & & & & & \\
\hline & Positive & 4 & 26.7 & 8 & 53.3 & $x^{2}=2.22$ & 0.14 \\
\hline & Negative & 11 & 73.3 & 7 & 46.7 & & \\
\hline & $8 w$ & & & & & & \\
\hline & Positive & 5 & 33.3 & 3 & 20.0 & $\mathrm{FET}=0.17$ & 0.68 \\
\hline & Negative & 10 & 66.7 & 12 & 80.0 & & \\
\hline & $12 w$ & & & & & & \\
\hline
\end{tabular}


Table 6 Comparison between the studied groups according to US changes through follow-up periods (Continued)

\begin{tabular}{|c|c|c|c|c|c|c|c|}
\hline \multirow[t]{2}{*}{ US changes } & \multirow[b]{2}{*}{ Positive } & \multicolumn{2}{|c|}{$\begin{array}{l}\text { CS injection group (15) } \\
\text { No. } \%\end{array}$} & \multicolumn{2}{|c|}{$\begin{array}{l}\text { ESWT group (15) } \\
\text { No. } \%\end{array}$} & \multirow{2}{*}{$\begin{array}{l}\text { Statistical test (FET) } \\
\text { FET }=0.54\end{array}$} & \multirow{2}{*}{$\begin{array}{l}p \text { valu } \\
0.483\end{array}$} \\
\hline & & 2 & 13.3 & 0 & 0.0 & & \\
\hline & Negative & 13 & 86.7 & 15 & 100 & & \\
\hline \multirow[t]{15}{*}{ Intra-tendon calcification and/or bone spurs } & Before & & & & & & \\
\hline & Positive & 4 & 26.7 & 2 & 13.3 & $\mathrm{FET}=0.21$ & 0.651 \\
\hline & Negative & 11 & 73.3 & 13 & 86.7 & & \\
\hline & $2 w$ & & & & & & \\
\hline & Positive & 4 & 26.7 & 2 & 13.3 & $\mathrm{FET}=0.21$ & 0.651 \\
\hline & Negative & 11 & 73.3 & 13 & 86.7 & & \\
\hline & $4 w$ & & & & & & \\
\hline & Positive & 4 & 26.7 & 2 & 13.3 & $\mathrm{FET}=0.21$ & 0.651 \\
\hline & Negative & 11 & 73.3 & 13 & 86.7 & & \\
\hline & $8 w$ & & & & & & \\
\hline & Positive & 4 & 26.7 & 1 & 6.7 & $\mathrm{FET}=0.96$ & 0.33 \\
\hline & Negative & 11 & 73.3 & 14 & 93.3 & & \\
\hline & $12 w$ & & & & & & \\
\hline & Positive & 4 & 26.7 & 0 & 0.0 & $\mathrm{FET}=2.60$ & 0.10 \\
\hline & Negative & 11 & 73.3 & 15 & 100 & & \\
\hline \multirow[t]{15}{*}{ Power Doppler signal } & Before & & & & & & \\
\hline & Positive & 2 & 13.3 & 3 & 20.0 & $\mathrm{FET}=0.0$ & 1.0 \\
\hline & Negative & 13 & 86.7 & 12 & 80.0 & & \\
\hline & $2 w$ & & & & & & \\
\hline & Positive & 2 & 13.3 & 2 & 13.3 & $\mathrm{FET}=0.0$ & 1.0 \\
\hline & Negative & 13 & 86.7 & 13 & 86.7 & & \\
\hline & $4 w$ & & & & & & \\
\hline & Positive & 2 & 13.3 & 1 & 6.7 & $\mathrm{FET}=0.0$ & 1.0 \\
\hline & Negative & 13 & 86.7 & 14 & 93.3 & & \\
\hline & $8 w$ & & & & & - & - \\
\hline & Positive & 0 & 0.0 & 0 & 0.0 & & \\
\hline & Negative & 15 & 100 & 15 & 100 & & \\
\hline & $12 w$ & & & & & - & - \\
\hline & Positive & 0 & 0.0 & 0 & 0.0 & & \\
\hline & Negative & 15 & 100 & 15 & 100 & & \\
\hline
\end{tabular}

CS, corticosteroid; ESWT, extracorporeal shock wave therapy; w, week; No., number

Newcomer et al. [32] also noticed no significant variations in the VAS and functional results, even in the short-term, in the steroid infusion group related to the placebo insertion group.

In the present study, VAS test showed a highly significant improvement among ESWT group after 2, 4, 8, and 12 weeks with $p<0.001$. These results are agreed with Pettrone and McCall [33] who found a high significant alleviation of pain intensity by VAS among LE patients who received ESWT.

Although the diagnosis of LE is mostly clinical, due to its countless benefits, US has been utilized as a useful imaging technique for the finding and follow-up of LE [34]. Ultrasound results in lateral epicondylitis have been well recognized with both structural variations [5] (tendon thickening, hypoechogenicity, intrasubstance tears, intratendon calcification, and bone spurs) and blood flow alterations or neovascularity [35]. Hypo echogenicity of common extensor origin tendon (CEO) is a strong evidence of chronic rather than acute LE. It reflects a chronically overused tendon [36]. In the current study, there was no statistically substantial alteration among the considered groups according to US changes (focal areas of hypo-echogenicity) through follow-up 


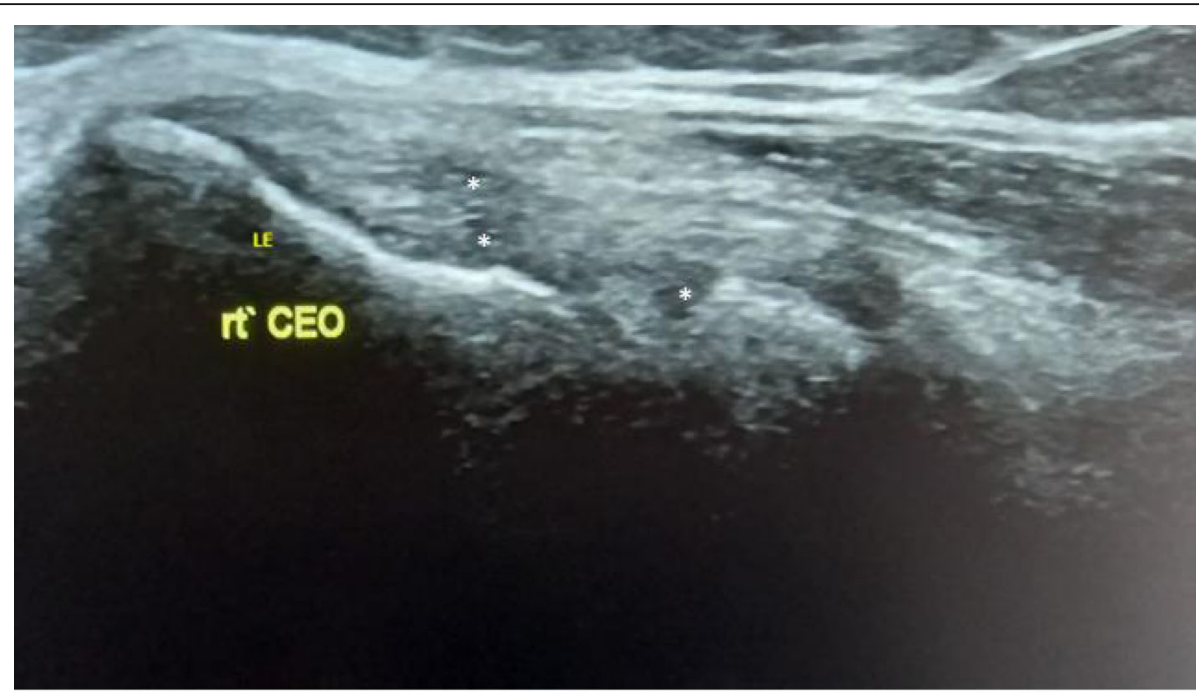

a: Longitudinal scan of lateral epicondyle showing focal hypo echogenicity and loss of fibrillar pattern of common extensor tendon in a lateral epicondylitis case before CS injection. LE: lateral epicondyle, CEO: common extensor origin.

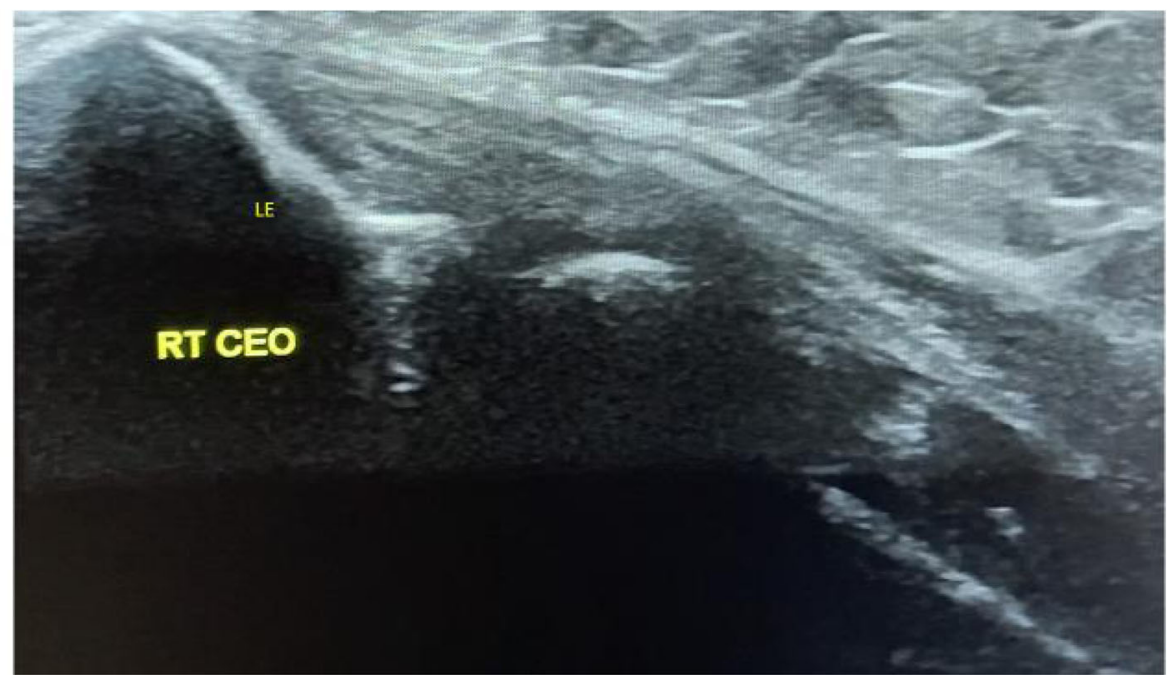

b: Longitudinal US scan of lateral epicondyle showing improvement of focal hypo echogenicity and fibrillar pattern of common extensor tendon in the same case after CS injection. LE: lateral epicondyle, CEO:common extensor origin.

Fig. 4 a Longitudinal scan of lateral epicondyle showing focal hypo echogenicity and loss of fibrillar pattern of common extensor tendon in a lateral epicondylitis case before CS injection. $\mathbf{b}$ Longitudinal US scan of lateral epicondyle showing improvement of focal hypo echogenicity and fibrillar pattern of common extensor tendon in the same case after CS injection

periods $(2,4,8$, and 12 weeks) and a statistically significant variance in favor of ESWT group regarding tendon thickening after 2 and 4 weeks of treatment. Other US parameters such as disturbed fibrillar pattern, intratendon calcification, and bone spurs, and power Doppler signals did not reveal considerable differences between the 2 groups although the ESWT group showed better US outcome. Up to date, no previous studies have used the musculoskeletal ultrasound in the comparison of outcome of both corticosteroid injection and ESWT.
Clarke et al. [37] evaluated sonographic prophets for tendon healing in patients with LE tendinopathy and noticed no parallel with clinical results and thickness of the tendon. Zeisiq et al. [34] tracked up 25 patients with LE after intertendinous injection treatment but could not reveal a correlation with structural variations in US and clinical findings.

In this study, there was a significant improvement in ESWT patients 2, 4, 8, and 12 weeks after treatment than local CS injection group which in line with the 


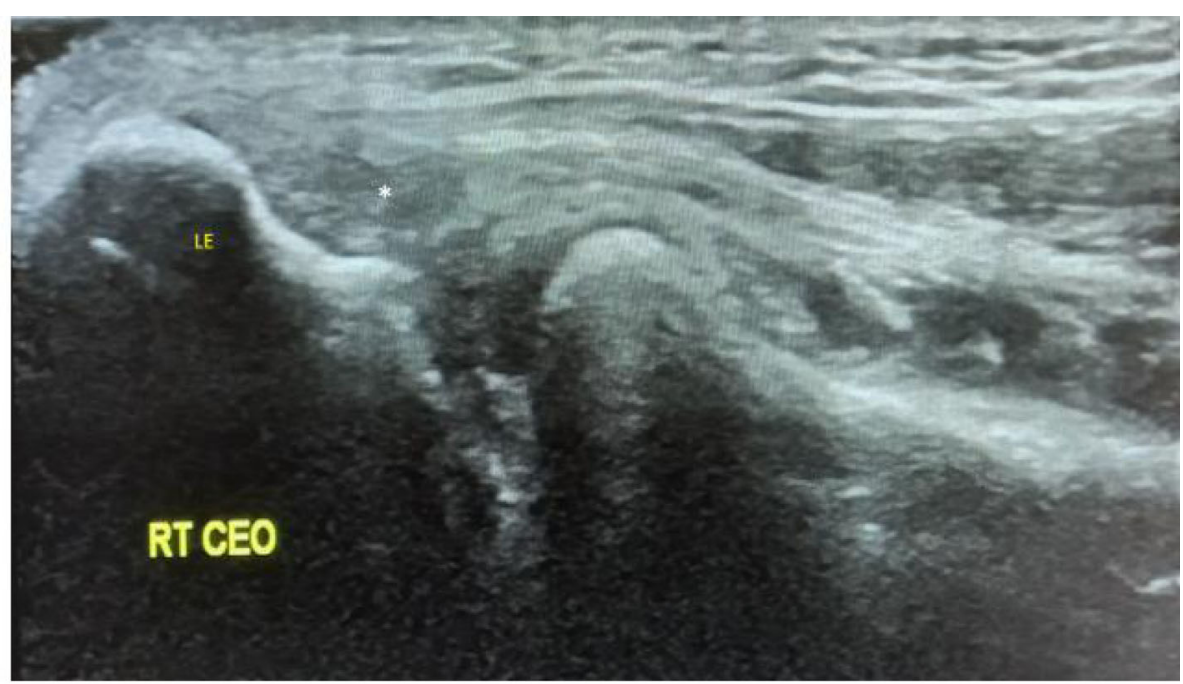

a:Longtudinal US scan of lateral epicondyle showing focal hypo echogenicity and abnormal fibrillar pattern of common extensor tendon in a lateral epicondylitis case before ESWT. LE: lateral epicondyle, CEO: common extensor origin.

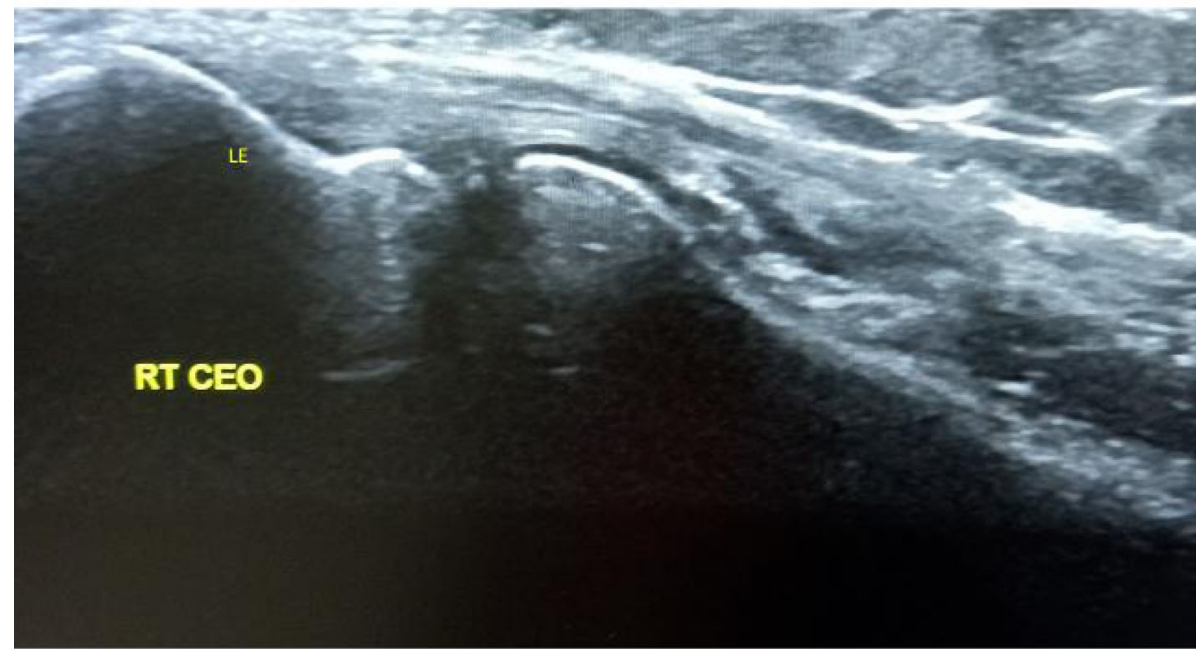

b:Longtudinal US scan of lateral epicondyle showing improvement of focal hypo echogenicity and fibrillar pattern of common extensor tendon in the same case after ESWT. LE: lateral epicondyle, CEO: common extensor origin.

Fig. 5 a Longtudinal US scan of lateral epicondyle showing focal hypo echogenicity and abnormal fibrillar pattern of common extensor tendon in a lateral epicondylitis case before ESWT. b Longtudinal US scan of lateral epicondyle showing improvement of focal hypo echogenicity and fibrillar pattern of common extensor tendon in the same case after ESWT

results of Lee et al. [4] who matched the usefulness of ESWT and corticosteroid insertion on patients with recently diagnosed LE and medial epicondylitis. They determined that ESWT was effectively considered as injections after therapy and during the 8-week followup.

Ozturan et al. [38] alienated 60 patients with a complaint > 6 months into 3 treatment groups and compared the effectiveness of corticosteroid injection, autologous blood, injection, and ESWT. In their study, while assessing patients with the Thompson test, upperextremity function scores, and grip strength during a 52week follow-up were assessed. He reported that the corticosteroid group was improved to the other groups at 4 weeks in terms of VAS and grip strength, but this superiority did not continue in the subsequent follow-ups. It was stated at 52 weeks of follow-up period that the corticosteroid injection had a success rate of $50 \%$, autologous blood injection had a success rate of $83 \%$, and ESWT had a success rate of $89 \%$. Eraslan et al. [39] drew 
similar conclusions. Thus, ESWT seems to validate greater long-term efficiency than corticosteroid injection.

However, this study has some limitation, including the relatively small sample size, few numbers of ESWT sessions (3 sessions only), and relatively short assessment period which was only 12 weeks.

\section{Conclusions}

Our study showed that both corticosteroid injection and ESWT were helpful and effective for lateral epicondylitis treatment; however, ESWT showed better results on long-term clinical and ultrasonographic follow-up than corticosteroid injection. We can consider ESWT for lateral epicondylitis athletes as its effective, safe, and noninvasive procedure. Both modalities showed a satisfactory structural improvement in common extensor tendon picture in ultrasonographic evaluation and follow up; we can consider musculoskeletal ultrasound as a convenient, safe, economic, and objective tool for diagnosis and follow-up of lateral epicondylitis.

In the light of this study, we recommend conduction of further studies and longer follow-up duration on larger sample size with special emphasis on athletes to gain satisfactory evidence regarding management of lateral epicondylitis. Further studies also are recommended to detect the optimal application parameters and settings of ESWT to obtain better results. More studies should be also conducted to evaluate musculoskeletal ultrasonography and power Doppler for both short- and long-term follow-up of lateral epicondylitis with special emphasis on athletes.

\section{Abbreviations}

LE: Lateral epicondylitis; ESWT: Extra corporeal shock wave therapy; NSAI Ds: Non-steroidal anti-inflammatory drugs; DASH: Disabilities of the arm, shoulder, and hand; PRTEE: Patient-rated tennis elbow evaluation; VAS: Visual analog scale; US: Ultrasound; CS: Corticosteroids

\section{Acknowledgements}

Not applicable.

\section{Authors' contributions}

All authors have read and approved the manuscript.

Idea suggestion; put the study design, data collection, and analysis; and sharing in writing of the manuscript: $\mathrm{NH}, \mathrm{AF}$, and MF

Manuscript writing and final revision: $\mathrm{NH}, \mathrm{AF}$, and $\mathrm{RM}$

\section{Funding}

The study did not receive any public or governmental funding.

\section{Availability of data and materials}

The datasets used and/or analyzed during the current study are available from the corresponding author on reasonable request.

\section{Declarations}

\section{Ethics approval and consent to participate}

Done. The Ethical Committee's approval: number: MS712019—date: January 7, 2019. Written consents according to Helsinki Declaration were taken from all patients and control subjects prior to participation in the study that were approved by the ethical committee of Faculty of Medicine, Benha University.

\section{Consent for publication}

The content of the manuscript has not been published or submitted for publication elsewhere.

\section{Competing interests}

The authors declare that they have no competing interests.

Received: 6 June 2021 Accepted: 14 August 2021

Published online: 03 November 2021

\section{References}

1. Taspinar O, Kepekci M, Ozaras N, Ayden T, Guler M (2014) Upper extremity problems in doner kebab masters. J Phys Ther Sci 26:1433-1436. https://doi. org/10.1589/jpts.26.1433

2. Bisset L, Paungmali A, Vicenzino B, Biller E, Herbert R (2005) A systematic review and meta-analysis of clinical trials on physical interventions for lateral epicondylalgia. Br J Sports Med. 39:411-422. https://doi.org/10.1136/bjsm.2 004.016170

3. Walrod, BJ (2014) Lateral epicondylitis overview. June 13, 2014: Medscape. http://emedicine.medscape.com/article/96969-overview. Accessed December 30, 2014.

4. Lee SS, Kang S, Park NK, Lee CW, Song HS, Sohn MK et al (2012) Effectiveness of initial extracorporeal shock wave therapy on the newly diagnosed lateral or medial epicondylitis. Ann Rehabil Med 36(5):681-687. https://doi.org/10.5535/arm.2012.36.5.681

5. Levin D, Nazarian LN, Theodore TT Miller T, O'Kane L, Feld I , et al (2005) Lateral epicondylitis of the elbow: US findings; Radiology Oct;237(1):230-234. doi: https://doi.org/10.1148/radiol.2371040784. Epub 2005 Aug 18.

6. Labelle H, Guibert R, Newman N, Fallaha M, Rivard CH (1992) Lack of scientific evidence for the treatment of lateral epicondylitis of the elbow. J Bone Joint Surg Br 74:646-651. https://doi.org/10.1302/0301-620X.74B5.13 88172

7. Crowther MA, Bannister GC, Huma H, Rooker GD (2002) A prospective, randomized study to compare extracorporeal shock-wave therapy and injection of steroid for the treatment of tennis elbow. J Bone Joint Surg Br. 84:678-679. https://doi.org/10.1302/0301-620X.84B5.12741

8. Haake M, Konig IR, Decker T, Riedel C, Buch M, Muller HH (2002) Extracorporeal shock wave therapy clinical trial group. Extracorporeal shock wave therapy in the treatment of lateral epicondylitis: a randomized multicenter trial. J Bone Joint Surg Am. 84:1982-1991. https://doi.org/10.21 06/00004623-200211000-00012

9. Wang CJ, Chen HS (2002) Shock wave therapy for patients with lateral epicondylitis of the elbow: a one- to two-year follow-up study. Am J Sports Med. 30:422-425. https://doi.org/10.1177/03635465020300031901

10. Rompe JD, Decking J, Schoellner C, Theis C (2004) Repetitive low-energy shock wave treatment for chronic lateral epicondylitis in tennis players. Am J Sports Med. 32:734-743. https://doi.org/10.1177/0363546503261697

11. Speed CA (2004) Extracorporeal shock-wave therapy in the management of chronic soft tissue conditions. J Bone Joint Surg Br. 86:165-171. https://doi. org/10.1302/0301-620X.86B2.14253

12. Gautam VK, Verma S, Batra S, Bhatnagar N, Arora S (2015) Platelet-rich plasma versus corticosteroid injection for recalcitrant lateral epiconsylitis: clinical and ultrasonographic evaluation. J Orthop Surg 23:1-5 (Hong Kong).

13. Rompe JD, Decking J, Schoellner C, Theis C (2004) Repetitive low energy shock wave treatment for chronic lateral epicondylitis in tennis players. Am J Sports Med 32:734-743. https://doi.org/10.1177/0363546503261697

14. Rompe JD, Hopf C, Kullmer K, Heine J, Burger R, Nafe B (1996) Low-energy extracorporeal shock wave therapy for persistent tennis elbow. Int Orthop. 20:23-27. https://doi.org/10.1007/s002640050021

15. Leung HB, Yen CH, Tse PYT (2004) Reliability of Hong Kong Chinese version of the Patient-rated Forearm Evaluation Questionnaire for lateral epicondylitis. Hong Kong Med J 10:172-177

16. Gummesson C, Ward MM, Atroshi I (2006) The shortened disabilities of the arm, shoulder and hand questionnaire (Quick DASH): validity and reliability based on responses within the full-length DASH. BMC musculoskeletal disorders. Dec 1;7(1):44. doi: https://doi.org/10.1186/1471-2474-7-44.

17. Maffulli G, Iuliano E, Padulo J, Rompe J, Gerdesmeyer L, Maffulli N (2018) Extracorporeal shock wave therapy in the treatment of tennis elbow. 
Muscles Ligaments Tendons J 8(3):423-429. doi: https://doi.org/10.32098/ mltj.03.2018.09, 2019.

18. Ismael M, Arafa M, El Zohiery A, Ibrahim S (2020) Comparative effectiveness of extracorporeal shock wave therapy, local corticosteroid injection, and conventional physiotherapy in treatment of chronic lateral epicondylitis. Egyptian Rheumatology and Rehabilitation. 47:25

19. Aydin A, Atic R (2018) Comparison of extracorporeal shockwave therapy and wrist-extensor splint application in the treatment of lateral epicondylitis: a prospective randomized controlled study. Journal of Pain Research 11: 1459-1467. https://doi.org/10.2147/JPR.S166679

20. Buchbinder R, Green S, Youd JM, Assendelft WJ, Barnsley L, Smidt N (2005) Shock wave therapy for lateral elbow pain. Cochrane Database Syst Rev 4. https://doi.org/10.1002/14651858

21. Staples MP, Forbes A, Ptasznik R, Gordon J, Buchbinder R (2008) A randomized controlled trial of extracorporeal shock wave therapy for lateral epicondylitis (tennis elbow). J Rheumatol 35:2038-2046

22. Reza Nourbakhsh M, Fearon FJ (2008) An alternative approach to treating lateral epicondylitis. A randomized, placebo-controlled, double-blinded study. Clin Rehabil 22:601-609. https://doi.org/10.1177/0269215507088447

23. Mehra A, Zaman T, Jenkin Al (2003) The use of a mobile lithotripter in the treatment of tennis elbow and plantar fasciitis. Surgeon 1:290-292. https:// doi.org/10.1016/s1479-666x(03)80048-3

24. Spacca G, Necozione S, Cacchio A (2005) Radial shock wave therapy for lateral epicondylitis: a prospective randomised controlled single-blind study. Eura Medicophys 41:17-25

25. Collins EDH, Jafarnia KK (2011) A clinical study of extracorporeal shock waves (ESW) for treatment of chronic lateral epicondylitis. Current Orthopaedic Practice 22:185-192. https://doi.org/10.1097/BCO.0b013e3182 Od830e

26. Iannone F, Notarnicola A, Lapadula G, Moretti L, Patella V, Garofalo R (2008) Extracorporeal shock waves down-regulate the expression of interleukin-10 and tumor necrosis factor-alpha in osteoarthritic chondrocytes. BMC Musculoskelet Disord 31(9):16

27. Bosch $G$, de Mos $M$, van Binsbergen $R$, van Schie $H T$, van de Lest $C H$, van Weeren PR (2009) The effect of focused extracorporeal shock wave therapy on collagen matrix and gene expression in normal tendons and ligaments. Equine Vet J 41(4):335-341. https://doi.org/10.2746/042516409×370766

28. Smidt N, Van Der Windt DAWM, Assendelft WJJ, Devillé WLJM, Korthals-de Bos IBC, Bouter LM (2002) Corticosteroid injections, physiotherapy, or a wait and-see policy for lateral epicondylitis: a randomised-controlled-trial. Lancet 359(9307):657-662. https://doi.org/10.1016/50140-6736(02)07811-X

29. Gaujoux-Viala C, Dougados M, Gossec L (2009) Efficacy and safety of steroid injections for shoulder and elbow tendonitis: a meta-analysis of randomised controlled trials. Ann Rheum Dis 68:1843-1849. https://doi.org/10.1136/ard.2 008.099572

30. Krogh TP, Bartels EM, Ellingsen T, Stengaard-Pedersen K, Buchbinder R, Fredberg U, Bliddal H, Christensen R (2013) Comparative effectiveness of injection therapies in lateral epicondylitis: a systematic review and network meta-analysis of randomized controlled trials. The American Journal of Sports Medicine. 41 (6):1435-1446. https://doi.org/10.1177/036354651245823 7

31. Lindenhovius A, Henket M, Gilligan BP, Lozano-Calderon S, Jesse BJ, David R (2008) Injection of dexamethasone versus placebo for lateral elbow pain: a prospective, double-blind, randomized clinical trial. J Hand Surg 33(6):909919. https://doi.org/10.1016/j.jhsa.2008.02.004

32. Newcomer KL, Laskowski ER, Idank DM, McLean TJ, Egan KS (2001) Corticosteroid injection in early treatment of lateral epicondylitis. Clin J Sport Med 11:214-222. https://doi.org/10.1097/00042752-2001 10000-00002

33. Pettrone FA, Mccall BR (2005) Extracorporeal shock wave therapy without local anesthesia for chronic lateral epicondylitis. The Journal of Bone and Joint Surgery-American Volume 87(6):1297-1304

34. Zeisiq E, Fahlstorm M, Olberg L, Alfredson H (2010) A two year sonographic follow-up after intratendinous injection therapy in patients with tennis elbow. Br J Sports Med 44:584-587. https://doi.org/10.1136/bjsm2008.04 9874.584

35. Weiberg EP, Adams MJ, Hollenberg GM (1998) Color Doppler sonography of patellar tendinosis. AJR Am J Roentgenol 171:743-744. https://doi.org/1 0.2214/ajr.171.3.9725308

36. Grassi W, Flippucci E, Farina A, Cervini C (2000) Sonographic imaging of tendons. Arthritis and rheumatism 43:969-976. https://doi.org/10.1002/15290131(200005)43:5<969
37. Clarke AW, Ahmad M, Curtis M, Connell DA (2010) Lateral elbow tendinopathy: correlation of ultrasonographic findings with pain and functional disability. Am J Sports Med 38:1209-1214. https://doi.org/10.11 77/0363546509359066

38. Ozturan KE, Yucel I, Cakici H, Guven M, Sungur I (2010) Autologous blood and corticosteroid injection and extracorporeal shock wave therapy in the treatment of lateral epicondylitis. Orthopedics. 33(2):84-91. https://doi.org/1 0.3928/01477447-20100104-09

39. Eraslan L., Yuce D., Erbilici A., and G. Baltaci(2018) "Does kinesiotaping improve pain and functionality in patients with newly diagnosed lateral epicondylitis?," Knee Surgery, Sports Traumatology, Arthroscopy, vol. 26, no. 3, pp. 938-945. doi: https://doi.org/10.1007/s00167-017-4691-7.

\section{Publisher's Note}

Springer Nature remains neutral with regard to jurisdictional claims in published maps and institutional affiliations.

\section{Submit your manuscript to a SpringerOpen ${ }^{\circ}$ journal and benefit from:}

- Convenient online submission

- Rigorous peer review

- Open access: articles freely available online

- High visibility within the field

- Retaining the copyright to your article

Submit your next manuscript at $\boldsymbol{\nabla}$ springeropen.com 